\title{
Preventing Illegal Logging with Local Wisdom? The Guguk Forest, Merangin, Jambi, Indonesia
}

\author{
Robi'atul Adawiyah; ; Dian Mukhlisa; ${ }^{\star \star}$ Akhdiat Nanda \\ Miharja ${ }^{\star \star \star}$ \\ UIN Sulthan Thaha Saifuddin Jambi \\ *robiatuladawiyah@uinjambi.ac.id

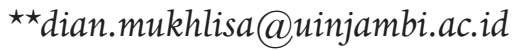 \\ $\star \star \star$ akhdiatnandamiharja@gmail.com
}

\begin{abstract}
This article explores the local wisdom of Guguk Village people in Merangin Regency in defending their Indigenous forests from illegal logging, committed individuals or multinational companies holding permits of Forest Concession Rights from the Government. This study aims to look at the role of the Guguk village community and their local wisdom in resolving illegal logging case in the Guguk Forest. Originally an empirical legal research, this study applied a qualitative approach in analyzing data from observation, interviews and documentation from the research. It is demonstrated that the Guguk Village community strongly hold a tradition in maintaining their traditional forest. The heads of tribes called "ninik mamak", religious leaders and community members were always involved in the efforts of preserving the Guguk forests. In addition, the administrator of the Guguk customary forest still uses a traditional process in settling illegal logging cases. The perpetrators of illegal logging will be subject to customary sanctions, where he must provide buffalo or goats as a punishment for their mistake as long as the forest exploitation is concerned. Some money has to be paid to support the village development. This method is proved to be effective in eradicating illegal logging in the Guguk forest.
\end{abstract}


Keywords: Illegal logging; Guguk forest; local wisdom; customary law.

\section{A. Introduction}

Indonesia is one of the countries with the largest tropical forest in the world after Brazil. The vegetation map of Indonesia in 1950 stated that $84 \%$ of Indonesia's land area was covered by dense forests, which is why Indonesia was once dubbed the emerald of and dominate the Equator. However, since the last few decades, Indonesia's forests have experienced tremendous shrinkage. The Guinness Book of World Records in 2008 once recorded Indonesia as the world's fastest forest destroying country, with a forest destruction rate of 2 million hectares per year. Forest Watch Indonesia data for 2018 shows that Indonesia's forest in the era of President Jokowi remains 43 percent of Indonesia's land area.

One of the main causes of forest destruction in Indonesia is the practice of illegal logging. The action includes logging activities in protected areas, conservation areas and national parks as well as cutting timber without permits in productive forests, inclduing transporting and trading illegal timber. Therefore, illegal logging can be understood as a violation of regulations as long excessive forest exploitation is concerned. ${ }^{1}$

Illegal logging activities without heeding forestry management principles to ensure the sustainability of forest resources has caused negative impacts in various aspects. The losses incurred have broad dimensions not only for economic problems, but also for social, cultural, political as well as environmental issues. The big loss is in the environmental aspect. The loss of a large number of trees results in environmental damage, decreased land productivity, erosion, flooding and climate change. Forest destruction can cause the extinction of species, including rare flora and fauna. All biodiversity and natural resources (including timber) may become extinct, so that future gen-

1 Tim Litbang Kehutanan, Review tentang Illegal Loging sebagai Acaman Terhadap Sumberdaya Hutan di Indonesia, Bogor: Badan Penelitian Dinas Kehutanan, 2011, p. 12 
erations cannot witness the mega-biodiversity wealth of Indonesia's tropical forests anymore. ${ }^{2}$

Illegal logging activities are rampant due to the high market demand for timber from Indonesia. Many forests have been suffered from illegal logging, one of which is the Guguk customary forest located in Guguk Village, Renah Pembarap District, Merangin Regency, Jambi Province. The forest is often the target of illegal logging committed by either individuals, groups or companies. ${ }^{3}$

At the end of 1990, a multinational company called Injapsin Company distructed the peaceful life of the people of Guguk Village. Injapsin Company is a joint venture company between Indonesia, Japan and Singapore which has a forest concession permit (FCP) in Merangin Regency covering an area of 61,000 hectares since 1984. This company has the permit No. 107/kpts-IV/88, dated 29-2-1988 with expiration date 29-02-2008. It turns out that approximately 200 hectares of Injapsin company's FCP are included in the Guguk Customary Forest. However, PT Injapsin continued to chop down a large number of trees and encroaches on the customary forest of $\mathrm{Gu}$ guk Village on the pretext that it has a permit from the government. This triggered the anger of the Guguk community who believed that Injapsin company had violated the boundaries in the Lantak Sepadan Charter which was also strengthened by the existence the Marga Pembarap map area made during the Dutch colonial era. Tensions escalated when the company made arrests of community members who were found to collect wood from the riverbank in the disputed area leading to conflicts between the company and the local community. ${ }^{4}$ This article aims to expose the struggle of the Guguk community in defending their customary forest from illegal logging. It also addresses the local wisdom in solving illegal logging.

2 Leden Marpaung, Tindak Pidana Terhadap Hutan, Hasil Hutan dan Satwa, Jakarta: Sinar Baru, 2007, p.1.

3 Interview with Sopian Hadi, leader of Guguk indigenous forest administrator, 30 March 2019

4 Datuk H. Abu Bakar, "Masyarakat Guguk" in Hutan Untuk Masa Depan Pengelolaan Hutan Adat di Tengah Arus Perubahan Dunia, Emilianus Ola Kleden (ed), Jakarta: Aman-DTE, 2013, p. 67-85. 


\section{B. Discussion}

\section{General Picture of Guguk Customary People}

The term "masyarakat adat (customary community)" or "masyarakat hukum adat (customary law community)" was a consequence of a grouping of people introduced by the Dutch Indies customary law thinker named Cornelis Van Vallenhopen. ${ }^{5}$ The category of social groups which became known as law communities (rechtsgemeenschappen) comprises all members of the community who are bound as one unit by the adat law. As the binding law is customary law, this community unit is called the customary law community (adatrechtgemeenschappen). ${ }^{6}$ The First Congress of Masyarakat Adat Nusantara (KMAN) or Archipelago Customary Community Congress I in March 1999 defined customary community as groups of people who have ancestral origins (from generation to generation) in certain geographic areas, and have a system of values, ideology, economy, politics, culture, society and territory of their own. ${ }^{7}$

Customary communities or customary law communities (CLC) are normatively regulated in article 1 number 1 on Regulation of the Minister of Home Affairs Number 52 of 2014. In this article, it is stated that indigenous peoples are Indonesian citizens who have unique characteristics, live in groups in harmony according to customary law. They has ties to ancestral origins or common place of residence, and have a strong relationship with land and the environment, as well as the existence of a value system that determines economic, political, social, cultural, legal institutions and utilizes one area from generation to generation. Generally, indigenous peoples have their own values of virtue and wisdom in dealing with nature that they have inherited from generation to generation.

5 J.F. Holleman (ed), Van Vollenhoven on Indonesian Adat Law, SpringerScience+Business Media, B.V. 1981.

6 Yance Arizona (ed), Antara Teks dan Konteks: Dinamika Pengakuan Hukum Terhadap Hak Masyarakat Adat atas Sumber Daya Alam Manusia, Jakarta: Huma, 2010, p. 4

7 Ibid. 
According to Moniaga, customary law communities in simple terms referred to as a community who live in a certain area with certain customs and cultures. This term is often used to identify a community after their own local identification such as Dayak people, the Kanekes (Baduy people), the Dani people, the Amungme people, the Kaili people and so on. ${ }^{8}$

In Jambi province, there is one indigenous community known for its success to protect the forest, namely the indigenous people of Guguk village. They live in Guguk village, located in Renah Pembarap Sub-district (formerly Sungai Manau District) Merangin District, Jambi Province. It is one of the villages which is located in the buffer zone of Kerinci Seblat National Park (TNKS), on the causeway connecting Merangin Regency and Kerinci Regency, two areas in Jambi Province. Administratively, the village of guguk in the northern area is bordered by Muara Bantan, in the south with Lubuk Beringin Village and the former HPH area of Injapsin company. The east is bordered by the village of Marus Jaya and the west is bordered by the village of Simpang Parit and the village of Parit Ujung Tanjung. ${ }^{9}$

Guguk village has a population of 1,181 people with 296 households, most of whom are Malay people, mainly from the Marga Pembarap. The minority comes from the ethnic of Javanese, Minang and Batak. The majority of the population are Muslims. In general, the main livelihood of the population is rubber farmers. ${ }^{10}$ Rubber plantation commodities have contributed to the prosperity of life for the villagers of Guguk. This can be seen from the number of permanent houses, the number of four-wheeled vehicles owned by the number of residents who attend university.

The village of Guguk is one of the old villages that the local community began to inhabit before the Dutch colonial period. The village of Guguk was formerly known as Pelegai Panjang and was the

8 Sandra Moniaga, Hak-hak Masyarakat Adat di Indonesia, dalam Sugeng Bahagio dan Asmara Nababan (ed), Hak Asasi Manusia Tanggung Jawab Negara, Peran Institusi Nasional dan masyarakat, Jakarta: Komnas HAM, 1999, p. 135.

9 This source was gathered from Geografi Desa Guguk in 2019

10 This source was gathered from Monografi Desa Guguk in 2019. 
seat of the Marga Pembarap government. Marga was a small form of government at that time whose leader was called "Depati". It is reported that the Pembarap clan came from the descendants of Mataram (Central Java) and Minangkabau (West Sumatra). The boundaries of the Pembarap clan are stated in a charter called "Lantak Sepadan", which was handed over by Sultan Anom Seri Mogoro from the Jambi Sultanate to Depati Pembarap (leader of the Pembarap region) on Monday, the month of Syafar 1170 Hijriyah or 1749 AD. ${ }^{11}$

It is stated in the Charter that "Hutan dan tanahnya itu hingga Teluk Serambi terus ke Tebat Gedang Tanjung Selasah terus ke bukit Cempedak turun ke Setepung merampung ke Ulu Masat terus ke Serik Bedjadjo habis bateh dengan Masumai terus ke pematang Batas Buluh apo berbatas dengan Depati Ma. Langkap terus ke Renah utan Udang berbatas dengan Serampas/dusun tuo terjun ke ulu Mangkanang berbatas dengan Sengrahan dan Tiang Pumpung seekor ikannya sebingkah tanahnya adalah milik Depati Pembarap" (The forest and the land are up to Serambi Bay, continue to Tebat Gedang Tanjung Selasah, continue to Cempedak Hill, down to Setepung, finish to Ulu Masat, continue to Serik Bedjadjo, then end up its border in Masumai, continue to the Buluh border, have a border with Depati Ma. Continue to Renah Utan Udang and have border with Serampas / dusun tuo down to Ulu Mangkanang, abut Sengrahan and Tiang Pumpung where the fish and the land belong to Depati Pembarap). ${ }^{12}$ The land that is included in the charter is called Tanah Depati or Tanah Batin. ${ }^{13}$

During the Dutch colonial era, the Dutch changed the name Depati to "Pasirah" and those who became Pasirah had to be descendants of the King of Jambi. From then on, the life of the people of

11 Lindawati dan Zaiyardam, "Konflik dan Integrasi dalam Masyarakat plural: Jambi 1970-2012” Jurnal Paramita, Vol.25, No. 2 (2018), p. 174

12 This is the recognition of the Javanese king of the existence of the Pembarap clan and the boundaries of their customary territories. According to history, Netherland colonized Jambi in 1858. Dedi Arman, Sejarah Jambi 1855-1950" in http://kebudayaan.kemdikbud.go.id/bpnb/sejarah-jambi1855-1950, June 22, 2020 .

13 Rakhmat Hidayat, "Menata Ruang Membangun Kesepahaman,” Majalah JKPP, No.11 (2006), p. 14 
Guguk village was regulated by a traditional adat institution where the leader was the customary head who was concurrently the village head. After Indonesian independence, the Government of the Republic of Indonesia enacted Law Number 5 of 1979 concerning Village Government. The law changes many things, among others are the structure of the village, starting from the uniformity of village government organizations throughout Indonesia to the democratization of villages, in which the village head was directly elected by the community. The Village Head regulates the formal life order according to the rules that apply in all regions of Indonesia. The law on village governance has weakened the existence of customary institutions including the Jambi Malay adat. As a result, some of the customs that have been used for generations disappeared. ${ }^{14}$

The Marga Pembarap who live in the Merangin Jambi area are still trying to maintain the rules rooted in old customs. The Guguk Customary Institution, which is commonly called "ninik mamak", is an assembly consisting of village elders. The Guguk customary institution consists of representatives from 4 kalbu (tribal leaders) in the Pembarap clan, namely Mengkai, Malindan, Senggerahan and Dagang. It is the customary leader who coordinates the heads of heart. Customary institutions together with syara' (religious) institutions are placed outside the government structure of Guguk village whose function is to regulate community life starting from land ownership procedures, natural resource management, social order and interactions such as marriage and death. To this day, this customary institution still has a fairly strong influence in the Guguk community, as the phrase "Adat lamo pusako usang," the adat which never vanishes inherited from generation to generation.

The customary rules that are still enforced are expressed in such a words as "Dusun nan bepagar adat, tapian nan bapagar baso, tebing nan bepagar undang, rumah nan berico, berpakaian berpantang berlarang." It is inferred from the wise words that the vaillage apply adat law in order to uphold morality among the community, not only in the way

14 Ni'matul Huda, Hukum Pemerintahan Desa dalam Konstitusi Indonesia sejak Kemerdekaan Hingga Era Reformasi, Malang: Setara Press, 2015, p.148 
of speaking and acting, but also of dressing. ${ }^{15}$ To prevent these customary rules from vanishing, every year in the village of Guguk, a traditional festival is held and attended by all the people of Guguk Village. In this feast, all problems faced by the Guguk community are resolved by customary deliberation.

The Guguk community is a society that adheres to tradition. They really respect and uphold the customs that have been passed down from generation to generation since the days of their ancestors. There is a very strong attachment in the relationship between community and adat. They are submissive and afraid that they violate adat which will result in customary sanctions. Not only because they are afraid to be ashamed of losing their self-respect and family, but also because they are afraid that they will be excluded from social interactions. Sanctions and social forces are the main keys of adat in maintaining community relations. ${ }^{16}$

\section{The Role of the People of Guguk Village in Preserving Customary Forests from Illegal Logging}

At the 2017 annual Land and Poverty Conference, the World Bank stated that one of the most effective ways to stop deforestation or deforestation is to grant formal land rights to local communities in tropical forest areas. Indigenous people have the best understanding of how to protect their precious forests. Local people are the most effective group to combat forest encroachment (illegal logging). A World Bank study of forests in six countries (one of which is Indonesia) shows significantly lower rates of deforestation in areas where communities have legal rights to manage forests and have government support, namely for management and law enforcement. ${ }^{17}$

15 Datuk H. Abu Bakar, "Masyarakat Adat Guguk" in https://www.downtoearth-indonesia.org/sites / downtoearth-indonesia.org/files/R-4-Guguk. pdf, accessed on 21 May 2020.

16 Devrian Ali Putra, "Hutan Adat dalam Perspektif Islam: Studi Kasus Hutan Adat Guguk Propinsi Jambi” in Indo-Islamika, Vol. 5, No. 1(2015), p. 133.

17 Hendra Pasuhuk, "Pengelolaan oleh Masyarakat Cara terbaik Hadapi Penebangan Hutan" in https: / / www.dw.com/id/pengelolaan-oleh-masyarakatcara-terbaik-hadapi-penebangan-hutan/a-38066292 accessed on 21 May 
One local community that has proven successful in forest conservation is the Indigenous People of Guguk Village, located in Ranah Pembarap Sub-district, Merangin Regency, Jambi Province. For the Guguk Indigenous people, the forest is an inseparable part of their lives. Customary forests provide various kinds of community needs for free. The woods in the Guguk forest are reserved for housing and public facilities. This forest produces rattan which is used to make various household tools and crafts. It also produces various kinds of medicinal plants such as pudding leaves and earth pegs which are useful for maintaining health. Every fruit season, people can enjoy and even sell forest fruits such as tampoi, bidaro, ambacang, rambutan to durian which mostly grow in the Guguk forest area.

The biodiversity survey conducted by the Indonesian Conservation Community (KKI-Warsi) shows that the level of biodiversity of the Guguk forest is still high. In the Guguk forest, 84 tree species were found, including tembesu, kulim, medang, meranti, balam, warsaw, rattan, manau, jernang and even agarwood thrives in this place. ${ }^{18}$ Even here, there are 89 species of birds, some of which include endangered and protected species such as hornbills, Murai Batu and Sawai as well as 22 endangered mammals such as tapirs and bears. In the Guguk forest there are still some rare animals such as tapirs, deer, jungle fowl, kuau birds and even Sumatran tigers that still inhabit the Guguk forest comfortably. ${ }^{19}$

Guguk Forest also has very high carbon stock which is very important in maintaining global climate balance. As the world's forests are becoming increasingly deforested, economic opportunities will emerge in the world carbon trading scheme. Guguk forest which is very wide and preserved will be one of the leading sectors of the forestry sector in the future. The Indonesian Conservation Community

2020.

18 Ratna Sari Gultom, "Studi Populasi Siamang (sympalangus syndactus Raffles, 1821) di Hutan Guguk Kabupaten Merangin Propinsi Jambi” in Jurnal Biocolony, Vol.2 No. 1 (2019), p. 29-31

19 Fajar Ahmad. "Keanekaragaman jenis Semut (Hymenoptera: Formicidae) di Hutan Guguk Kabupaten Merangin Jambi” dalam Jurnal Biocolony, Vol.2, No.1 (2019), p. 29-31 
(KKI) Warsi together with ICRAF have studied carbon stocks in the Guguk Village Customary Forest using the RaCSA (Rapid Carbon Stock Assessment) methodology. As a result, carbon reserves reached 261.25 tons / hectare. If it is sold with an assumption of US \$ 10 per ton carbon with a forest area of 690 hectares, a year it could generate US $\$ 1.8$ million or Rp. 25.2 billion (exchange rate $1 \mathrm{USD}=14,000$ ). ${ }^{20}$ The Guguk Forest is a very valuable wealth for present and future generations.

As a sovereign community, the people of Guguk have their own written rules regarding forest use from time immemorial in the form of a charter. The Charter states that "Satu tetes airnya, satu bingkah tanahnya, satu ekor ikannya adalah milik Depati Pembarap....Ke air samasama diberikan ikan. Ke darat sama-sama dipaomo" (One drop of water, one piece of land, one fish belongs to Depati Pembarap .... to the water (river) fish are shared together, to the garden are cultivated together). This implies that all natural wealth belongs to the local indigenous people and they have the same rights to access and utilize all of these natural resources. Apart from that, there is also a regulation regarding the community's obligations which reads "Ke air berbunga pasir, ke darat berbunga kayu, tambang pendulang berbunga daun, umo ladang berbunga kelemping, terkecuali hasil-hasil tersebut untuk dipakai sendiri" (the water produces sand, the land produces wood, to mining is filled with leaves, the garden with small flowers, unless these products are for their own use). This means that the use of Depati or Batin land by community members is subject to levies or taxes according to the agreement with the customary institution. These levies will then be submitted to the leader of the pemarap clan called Depati to be used for the benefit of the community in that area. ${ }^{21}$

On the other hand, the enactment of Law Number 1979 concerning Village Government not only weakens the influence of Cus-

20 Bambang Tri-Sasongko, "Pasar Karbon Perhutanan Sosial”, in www.forestdigest.com, Juni 22, 2020.

21 Datuk H. Abu Bakar, "Masyarakat Adat Guguk" in http:www.downtoearthindonesia.org/sites/ downtoearth-indonesia.org/files/R-4-Guguk, May 21, 2020. 
tomary institutions, but also affects the ownership and management of customary forests. Everything that used to be customary forest changed the status to private or state land. This change in formal legal status made the indigenous people of Guguk Village lose their collective rights to customary forests which belonged to the state. When the state or government handed over forest management to companies through forest concession rights $(\mathrm{HPH})$, the Guguk people did not have the right to defend it. This is what happened when the government made the forest in the Pembarab clan area as production forest and handed over the forest concession rights to Injapsin Company, the indigenous people are powerless against it.

As Injapsin company started cutting down trees in the customary forest area, the Guguk people started to rebel. In fact, the community has long wanted them to be empowered to manage forests according to customary means. At the same time, the government began to proclaim the Era of Regional Autonomy with the enactment of Law Number 22 of 1999 concerning Regional Government. The Guguk community began to have the courage to claim their sovereignty over the forest area that had been confiscated. The Guguk community complained to the Merangin Regional Government and urged that the village forest in the Bukit Tapanggang area be saved. Datuk Abu Bakar, the adat leader, also complained about this problem at the first Congress of the Alliance for Indigenous Peoples of the Archipelago (AMAN) in Jakarta in 1999. It turns out that the Guguk forest conflict is just one of the many cases of tenurial conflicts between indigenous peoples and forest use companies throughout Indonesia such as IUPHHK-HA, IUPHHK-HT, oil palm and mining.

Facilitated by the Indonesian Conservation Community-Conservation Information Center (KKI-Warsi) as a non-governmental organization concerned with saving the environment, in 1999, a meeting of the Guguk Village community with the Merangin Government and also PT Injapsin was arranged. During the meeting it was finally revealed from the Forestry Service data that the map used by Injapsin company was wrong. The company was proven to have breached the border into the area of the Pembarap clan, which includes the 
villages of Guguk and Parit Ujung Tanjung, covering an area of two hundred hectares. The two sides then made an agreement on their respective territorial boundaries. Finally, Injapsin company acknowledged the mistake of those who violated the boundaries of the $\mathrm{HPH}$ permit. With the approval of Injapsin company, through letter number $01 / \mathrm{Js} / \mathrm{IX} / 1999$, the \pm 200 Ha customary forest area which was originally included in the Injapsin. Co HPH concession was returned to the Customary Forest Area of Guguk village at the end of 1999.22

This is a rare event especially in the New Order era, which fully supported the HPH concession system policy. It is very rare in Indonesia that indigenous peoples with their very modest circumstances succeeded in fighting against a large corporation which certainly has extraordinary power. The essence of this victory is actually the recognition of the rights of indigenous peoples to natural resources which they have inherited from their ancestors long before the Indonesian state was formed.

The Guguk community wants the remaining forest in the Tapanggang hill area to become customary forest. The Regent of Merangin responded to this by issuing a Decree of the Regent of Merangin Number: 287 of 2003 concerning the Customary Forest of the Guguk Customary Law Community. The inauguration and inauguration were carried out in a very festive traditional ceremony. In this activity, two matters were agreed regarding the utilization and management of the Guguk forest. First, there is a regulation regarding the management of the Guguk forest which is then contained in the Charter of the Agreement on the Maintenance and Management of the Traditional Forest in the Village of Guguk. This agreement was signed by the village head, hamlet head, traditional leaders, religious leaders, women leaders, youth and village representative bodies. Second, the Guguk Village Customary Forest Management Group (KPHA) was formed as stipulated in the Joint Decree No.1.KB/VIII/ 2003.

The Guguk community is not satisfied if the Guguk customary 
forest is only legalized by a Regent Decree alone. Because they realize that without the support of official regulations from the government, the customary agreement will not perform Hajj or will not have legal force. Finally, the status of customary forests was strengthened in the form of Village Regulations (Perdes). Perdes is very important because with it, people can no longer act arbitrarily towards the Guguk forest. And if this customary law is not obeyed and obeyed, then those who violate will be resolved in a formal law through state law.

Village regulations regarding the management and utilization of the Guguk customary forest are full of local wisdom values held by the Guguk community. The regulation states that the community is prohibited from making fields or gardens that are in customary forest areas. Fields or gardens that were already in the customary forest area before the existence of the perdes, cannot be expanded, but the owners can still use them by planting tree crops. The community is also prohibited from fishing in the customary forest area of Guguk Village by using poison, tuba, electricity (stun), explosives and a compressor machine. ${ }^{23}$

The village regulation also allows the community to take forest fruit on the condition that it does not damage the tree. There is even a special rule that durian trees cannot be climbed. This rule is based on the belief of the local community that a durian tree that is climbed will no longer bear fruit and will even die. ${ }^{24}$ In addition, there are special rules regarding timber that can be collected in the Guguk forest. First, logs that may be taken or felled are already at least fifty centimeters in diameter or have a circle of one hundred and fifty-seven centimeters, the height of the minamal is as high as an adult's shoulder or one point three meters. The wood or tree must be 25 meters away from the river and must not take wood from the mother tree. In one year, the maximum amount of wood that can

23 https: / / adoc.tips / piagam-kesepakatan-pemeliharaan-dan-pengelolaan-hutan-adat-d.html, 21 June 2020.

24 Devrian Ali Putra, Devrian Ali Putra, "Hutan Adat dalam Pespektif Islam: Studi Kasus Hutan Adat Guguk Propinsi Jambi," Jurnal Indo-Islami$k a$, Vol.2, No.2 (2015), p. 109-146, see also http:// repository.uinjambi. ac.id/1148/1/14789-42610-1-SM,pdf, accessed on 8 July 2020 
be extracted from the Guguk forest is 30 cubic meters. If it has exceeded the maximum cutting limit in one year, the people who have obtained the permit must wait in the following year. Second, every time 1 tree is cut, it is obligatory to replace it with planting 5 tree seedlings. Third, the wood may not be traded. Fourth, every harvest of Guguk wood and forest products is subject to "bungo kayu", a customary term for the payment of a fee (retribution) for harvesting customary forest timber. The Bungo timber measure that must be paid for each timber or tree harvested by the Guguk community members is thirty percent of the market price. For fruit, the wooden bungo is one-third of the fruit picked from the Guguk forest.

The proceeds from this wooden bungo or customary retribution will be used for training the village of Guguk. The arrangements include forty percent for the village treasury, thirty percent for the treasury of the Customary Forest management group, twenty percent for the heart treasury and ten percent for the youth organization. This means that the funds obtained will be returned and used for the prosperity of the Guguk village community itself.

The people of Guguk village believe that they are obliged to protect the Guguk forest because it is an inheritance for their later children and grandchildren. For this reason, the community has created a legal fort so that the area can be safe from exploitation by irresponsible parties. The affirmation of the Guguk customary forest through the Merangin Regent's Decree which was later strengthened by a village regulation for its maintenance was a genuine growing community awareness of the importance of the forest for the survival of them and their grandchildren. At that time, it was still very rare in Indonesia, with a Village Regulation that specifically regulated the management and maintenance of customary forests. The Guguk community was the pioneer.

The indigenous people of Guguk village are proven to be able to support their own life and safety and at the same time support the socio-ecological services of nature for the needs of all living things. With social institutions that are friendly to nature, the people of $\mathrm{Gu}-$ guk Village have sufficient capacity to carry out rehabilitation and re- 
store forest damage in the former HPH concession areas of Injapsin company.

\section{Local Wisdom Values in Resolving Illegal Logging Cases in the Traditional Forest of Guguk Village}

The Guguk customary forest is often the target of illegal logging by individuals, groups and forestry companies. If at the end of 1990 Injapsin company plundered the customary forest, in the 2000s, the Guguk customary forest area was often encroached by a group of people outside the Guguk area. On several occasions, outsiders have been caught cutting trees, taking wood, and clearing plantation land in the Guguk forest area secretly. The squatters are of course dealing with the people of Guguk Village who are known to be very persistent in protecting the forest and their environment.

Community members do not hesitate to report to the customary forest management group (KPHA) if they see or know of illegal tree cutting activities in the Guguk forest. The perpetrators who were caught by the KPHA were reported to the Guguk Village Customary Institution to be processed according to the applicable regulations in Guguk Village. The process of solving illegal logging cases in the Guguk forest still uses traditional processes which are full of local wisdom values. ${ }^{25}$ The settlement process is imbued with the spirit contained in the seloko ${ }^{26}$ or local custom petitih inscriptions. They are:

First, the settlement of illegal logging is carried out by delib-

25 A local wisdom is nothing but the wisdom in perceiving lives in peace and harmony. Such a way of ethics is taught and inherited through generations through such ways as oral literature, implemented in the forms of language and poems/proverbs. Muhammad Risal, "Kearifan Lokal dalam Pembentukan Daerah Otonomi Baru di Era Otonomi daerah (Studi Kasus: Kearifan Lokal di daerah Apau Kayan kabupaten Malinau)" Jurnal Administrative Reform, Vol.4, No.2, (2016), p. 112

26 The seloko is one of the oral tradition of Jambi people used to express messages or advices and they are believed to have ethical and moral values as well as norms to comply with. Junaidi T. Noor, "Seloko; Tradisi Lisan Masyarakat Melayu Jambi (Ditinjau dari Sudut Pandang Sosbud)", paper, (2013), p.30 
eration and consensus in accordance with the customary expression "Keruh dijernihkan, bengkok diluruskan, semak di hulu dikehulukan, semak dihilir dikehilirkan, semak di tengah dikampungkan. Negeri aman padi menjadi, air bening ikannyo jinak, rumput mudo kerbaunyo gemuk, tidak ada kusut yang tidak dapat diselesaikan, tidak ada keruh yang nan tidak dapat dijernihkan" (the cloud is clarified, the curve is straightened, the bushes upstream are set up upstream, the bushes downstream are set up downstream, the bushes in the middle are settled. The safe land with the plenty rice, the clear water with the tame fish, the fresh grass with the fat buffalo, there are no tangles that cannot be resolved, there is no cloudiness that cannot be clarified). The adat law teaches how to dispute is resolved by way of peace, strategy, with positive minds and harmonious life. Customary deliberations are held to obtain such a 'win win solution'. That is, neither of the parties to the dispute feel that they have been disadvantaged or won. Instead, both of them felt that they both benefited in the settlement process. In such a way, the settlement of dispute is like "Ibarat menarik benang dalam tepung, benang tidak putus tepung tidak terserak" (Like pulling the threads out of flour, the threads would not be broken and the flour would not be scattered).

This is why the customary sanction is in the form of livestock such as buffalo and goat which are equipped with complete cooking spices. The point is that the animal will be slaughtered and cooked. The results will be eaten together by illegal logging actors and the entire Guguk village community. They will sit together, forgiving each other, without resentment and resentment. In addition, the purpose of holding the joint meal is so that all people in society realize that protecting the Guguk forest is a shared responsibility and the benefits will return to themselves and their children and grandchildren later. What is done by the indigenous people of Guguk Village is something that is very extraordinary in preserving the forest. The people of Guguk Village have succeeded in applying customary law in an era that is already consistent in the application of customary law.

Second, the settlement process is carried out in stages according to the customary expression "Bertangkap naik. Bertangga turun". This 
means that every customary issue is first conveyed in stages according to its degree, starting from tuo tengganai, then conveyed to ninik mamak, the traditional leaders. From ninik mamak then to Mangku. From mangku to Depati. Depati will then invite the meeting. In the context of modern times, the settlement of illegal logging in the $\mathrm{Gu}$ guk forest is carried out in customary meetings involving traditional leaders called ninik mamak, religious leaders, village leaders to the local community. It is in this customary meeting that the guilty party will be determined and will be subject to customary sanctions or fines. If it cannot be resolved in a family manner, it will be reported to the police for further action and punishment according to state regulations.

For example, the settlement of illegal logging cases carried out by residents from outside Guguk Village in 2017. This case was preceded by a report from the community who heard the sound of a wood cutting tool (chain shaw) sounding in the Guguk forest to KPHA officers. KPHA will review the report. Illegal logging perpetrators who are caught will be processed amicably in the deliberations of the Guguk customary institution. The customary forest manager confiscated the goods or tools used by the perpetrator in the illegal logging process and ordered the perpetrator to send a ninik mamak or traditional leader from the perpetrator's village to be consulted. The management of the Guguk customary forest will provide a period of two weeks to bring in the ninik mamak. If the perpetrator does not want to follow the order, then the case will be transferred to the authorities, namely the local police. ${ }^{27}$

Third, the customary sanctions applied are in line with the expression "Wrong eating in a meal, wrongly bringing it back, wrong using it will pass." This means that whoever has committed an offense which results in a loss, then he must replace or pay for the loss caused. For people who are found guilty of cutting trees without permission or not in accordance with the applicable regulations in the Guguk forest, besides having to pay bungo timber or customary

27 Interview with Sopian Hadi, leader of Guguk indigenous forest administrator, March 30, 2019. 
retribution, they are also required to pay customary fines.

According to Devrian Ali in his writing entitled "Customary Forests in an Islamic Perspective: Case Study of the Guguk Customary Forest of Jambi Province", generally the customary sanctions for every violation of the law in the Jambi area are relatively the same, only different provisions regarding the category of violation and the type of punishment are called ico-use. Customary violations are grouped into three types, namely serious, moderate and minor violations. For serious violations, customary sanctions are imposed in the form of paying for one buffalo, one hundred bushels of rice, one hundred coconuts and their accessories which are called 'selemak semanisnyo'. As for the minor violation category, the fines were in the form of one goat, twenty bushels of rice, twenty coconuts and "as sweet as fat". Meanwhile, for minor violations in the form of a fine of twenty coconuts or a chicken. ${ }^{28}$

Regarding the sanctions for illegal logging perpetrators, in the Charter of Agreement on the Maintenance and Management of Customary Forest Guguk, Renah Pembarap District, Merangin Regency, it is explained that if there is a group of people or community members both from the local village and people outside the village who violate the provisions of customary forests, they will be subject to sanctions in the form of below:

First, for violations, such as cutting down trees in the Guguk forest with the aim of selling and trading the wood or opening up plantation land, the legal sanction is in the form of one buffalo, one hundred bushels of rice and one hundred coconuts, as sweet as fat or a fine of twenty-five million rupiah. The timber and felling tools will be confiscated for the village. Second, moderate violations take the form of taking customary forest products without a permit or taking forest fruit by cutting and destroying the trees or fishing in customary forest areas using poison, tuba or explosives. For this species, customary sanctions are imposed in the form of one goat, twenty

28 Devrian Ali Putra, "Hutan Adat dalam Pespektif Islam: Studi Kasus Hutan Adat Guguk Propinsi Jambi," in http://repository.uinjambi. ac.id/1148/1/14789-42610-1-SM,pdf, accessed 8 July 2020 
bushels of rice, twenty coconuts, and as sweet as fat. Third, minor violations such as catching fish by electrocuting or using a compressor will be subject to sanctions according to the results of the Guguk customary deliberations.

Sanctions for customary violations in the category of customary law have been imposed on Injapsin Company, who was found guilty of logging in the customary forest area of the Guguk community. Injapsin Company was demanded to pay customary fines in the form of a buffalo, three hundred and twenty kilograms of rice, one hundred coconut, semisnyo fat in the form of cooking spices, coffee, tea and sugar as well as a fine of twenty two million rupiah. The fine money will be handed over as village development money. Injapsin Company is willing to pay the compensation and conduct village development in the vicinity of the former concession area which it has annexed.

This heavy sanction has also been applied to community members outside the village of Guguk who cut timber to be traded in 2017. In the deliberation between Ninik Mamak, the perpetrator and Ninik Mamak, the village of Guguk, negotiations took place for the amount of customary fines from IDR. 25,000,000 to IDR. 15,000,000, this is because the area of the Guguk Customary Forest that was encroached by the perpetrator is not very large, namely 2 hectares and not too much wood is taken.

After determining the sanctions or fines that must be paid by the perpetrator, the IDR. 15,000,000 fine is handed over to the Head of the Guguk Customary Forest management to distribute according to their respective portions listed in the Charter of Agreement. For the fine of 1 buffalo, 100 bushels of rice, 100 coconuts, and as sweet as selemak are managed by the people of Guguk Village by processing them into dishes and eating them together by the people of Guguk Village and the perpetrators of illegal logging or Illegal Logging.

Fourth, the effectiveness of social sanctions in enforcing illegal logging laws. The law will be effective and obeyed by people because of awareness, sanctions, pressure and the social environment. The social environment has a very important role in greatly influencing 
the growth of a person's motivation to obey or break the law..$^{29}$ In the case of illegal logging in the Guguk forest, the perpetrators who were caught not only received material sanctions but also social sanctions in the form of exclusion and isolation from the associations of the Guguk community. The perpetrator will get different treatment from the local community. This creates shame and a sense of deterrence from repeating these mistakes. This is why, none of the illegal logging actors of the Guguk forest come from the local community. Most of them come from outside the Guguk area.

Law enforcement for illegal logging perpetrators through the application of customary law is very effective in protecting the $\mathrm{Gu}$ guk forest from illegal logging. Indigenous people are the ones most affected by illegal logging, therefore they voluntarily unite to protect the forest. Thanks to the persistence and seriousness of the indigenous people in protecting their forests, the Guguk community received many awards. In 2005, the people of Guguk were awarded the Kalpataru Jambi Province level environmental savior award. In 2007, Guguk Village received another CBFM (Community Based Forest Management) Award from the Minister of Forestry of the Republic of Indonesia, MS. Kaaban. Then in 2014, the Guguk Customary Forest received the National Kalpataru award for the category of Environmental Saver. Guguk Forest has been recognized as the pioneer of customary forest in Indonesia.

Now, Guguk forest is used as one of the natural tourist destinations in Merangin district. Many domestic and foreign tourists visit the Guguk Forest who wants to learn how to treat nature properly. To conserve the forest, the Guguk community is wise and not exploitative. Sustainable forest, prosperous community.

\section{Conclusion}

There are several things that can be concluded: first, the Guguk community with their local wisdom plays an important role in saving the

29 Soerjono Soekanto, Effektifitas Hukum dan Peranan Sanksi, Bandung: Remaja Karya,1998, p.60. 
Guguk forest from illegal logging. Second, to this day, the settlement of illegal logging cases in the Guguk forest still uses a traditional process that is full of local wisdom values and this has proven to be effective in eradicating illegal logging in the Guguk forest. Suggestion The indigenous people of Guguk, with their local wisdom, are proven to be the best forest keepers. With this fact, the government should make it easier to regulate the recognition of customary community rights over natural resources that have been inherited from generation to generation. Through customary forest schemes, sustainable forests, prosperous communities.

\section{Bibliography}

Ali Putra, Devrian. 2015. Hutan Adat dalam Perspektif Islam: Studi Kasus Hutan Adat Guguk Propinsi Jambi. Jurnal Indo-Islamika, Vol. 5. No. 1.

Arizona, Yance. 2010. Antara Teks dan Konteks: Dinamika Pengakuan Hukum Terhadap Hak Masyarakat Adat atas Sumber Daya Alam Manusia. Jakarta: Huma,.

Bahagio, Sugeng dan Asmara Nababan. 1999. Hak Asasi Manusia Tanggung Jawab Negara, Peran Institusi Nasional dan masyarakat. Jakarta: Komnas HAM.

Fajar, Ahmad. 2019. "Keanekaragaman jenis Semut (Hymenoptera: Formicidae) di Hutan Guguk Kabupaten Merangin Jambi,” Jurnal Biocolony, Vol.2. No.1.

Hidayat, Rakhmat. 2006. Menata Ruang Membangun Kesepahaman. Majalah JKPP, No.11.

Holleman, J.F. (ed). 1981.Van Vollenhoven on Indonesian Adat Law, Springer-Science+Business Media, B.V.

Huda, Ni'matu. 2015. Hukum Pemerintahan Desa dalam Konstitusi Indonesia sejak Kemerdekaan Hingga Era Reformasi. Malang: setara Press.

Kleden, Emilianus Ola. 2013. Hutan Untuk Masa Depan Pengelolaan Hutan Adat di Tengah Arus Perubahan Dunia. Jakarta: Aman-DTE.

Lindawati dan Zaiyardam. 2018. Konflik dan Integrasi dalam 
Masyarakat plural: Jambi 1970-2012. Jurnal Paramita. Vol. 25. No. 2.

Marpaung, Leden. 2007. Tindak Pidana Terhadap Hutan, Hasil Hutan dan Satwa. Jakarta: Sinar Baru.

Risal, Muhammad. 2016. Kearifan Lokal dalam Pembentukan daerah Otonomi Baru di Era Otonomi daerah (Studi Kasus: Kearifan Lokal di daerah Apau Kayan kabupaten Malinau. Jurnal Administrative Reform. Vol.4. No.2.

Sari Gultom, Ratna. 2019. Studi Populasi Siamang (sympalangus syndactus Raffles, 1821) di Hutan Guguk Kabupaten Merangin Propinsi Jambi. Jurnal Biocolony 1, vol. 2.

Soekanto, Soerjono. 1998. Effektifitas Hukum dan Peranan Sanksi. Bandung: remaja Karya.

Tim Litbang Kehutanan. 2011. Review tentang Illegal Loging sebagai Acaman Terhadap Sumberdaya Hutan di Indonesi.Bogor: Badan Penelitian Dinas Kehutanan.

T. Noor, Junaidi. 2013. "Seloko; Tradisi Lisan Masyarakat Melayu Jambi (ditinjau dari sudut pandang sosbud)”, makalah. 